IJLRES - International Journal on Language, Research and Education Studies

ISSN: 2580-6777 (p); 2580-6785 (e)

Vol. 1, No. 2, 2017

Page: 270 - 285

\title{
CHARACTER EDUCATION OF CHILDREN'S PERSPECTIVE IBN QAYYIM AL-JAWZIYYAH (691 H - 752 H)
}

\author{
Makmudi \\ Ibnu Khaldun University of Bogor, Indonesia \\ makmudibogor@gmail.com
}

\begin{abstract}
The main problematic that caused the crisis of character in children is not making belief as basic philosophical in education. So, the implication of this is freedom of excessive euphoria. The success of the child based only from the perspective of the child's success in academic course. While the values of ethics, morals, and character less getting serious attention. Therefore, even though the students excel in intelligence quotient (IQ), but in emotional quotient (EQ) they are in crisis of becoming alarming character. In this context, the existence of children's character education is considered very important for the next generation as an integral part of their life and living. The purpose of this study was to determine the thinking of Ibnu Qayyim al-Jawziyya about the concept of character education of children. The method of writing this research use library research (library research), the research done by collecting data and information by reading, studying and then analyze literatures relating to the theme, both primary (primary sources) and secondary (secondary sources). Then analyzed using content analysis method (content analysis) in the form of descriptive-Analytic. The results of the research in this dissertation shows that the concept of character education of children according to Ibnu Qayyim al-Jawziyya emphasis on the four major ways : 1. The importance of introducing kids about the monotheistic God, 2. The need to teach children the principal teachings of religion, 3. Teach and familiarize children on good ethics and morals, 4. Modeling, 5. Praise and meaningful punishment.
\end{abstract}

Key Words: Education, Character, Ibn Qayyim al-Jawziyya Concept

\section{INTRODUCTION}

Rise of globalization (liberalization) often leads to faltering cultural values that hold true of a nation, as a result of identity and moral values degradation that hold true life. Adian Husaini noted, "has been widely understood that the wave of global cultural trend today largely a product of the West, spread around the world via electronic technology advantages and various forms of media and communication systems. Terms such as colonization of culture (cultural imperialism) colonization media (media imperialism), eviction cultural (cultural cleansing), a dependency culture (cultural 
dependency), and the occupation of electronics (electronic colonialism) is used to describe the global culture in new and various consequences on society of non -Western. "(Adian Husaini,, 2005:20).

This means that the effects of globalization increasingly leads to a new form of colonialism that imperialism Western culture to other cultures of the world. The effects of globalization can be an erosion of one's faith. This is the main problem of the crisis of character in children. Those cause of the weakening of the quality of students and the quality of the output produced from an education, especially in terms of morals, ethics, and values character personality in religious life and the nation. Therefore, the reemergence of the idea of character-based education today, based by the growing erosion of character and personality began fading as a nation, as well as well as human development efforts righteous morals and noble character. Therefore, it should be conceived character education of children as a form of coaching the national identity to students.

\section{REVIEW LITERATURE}

Before the authors discuss more about character education of children, firstly, the author will define these three terms separately. Those are : the notion of education, character, and children. Here, the authors describe some of the opinions of experts on these terms.

Education etymologically, can be defined as the process of changing attitudes and code of conduct individual or group in an effort to mature human being through the efforts of teaching, training and coaching. Education can also mean the process, ways and works to educate (Alwi, 2002: 263). According to Park (1960: 3) says that education is the art of imparting or acquiring knowledge and instructional trough as study habits.

While the meaning of the terminology, education can be interpreted as a conscious and deliberate effort to create an atmosphere of learning and the learning process so that learners are actively developing the potential for him to have the spiritual power of religion, self-control, personality, intelligence, character and the skills required by him, society, nation and state (Anwar Arifin, 2003: 34) 
Thus, the definition of education is a conscious and planned effort made by educators for learners to create an atmosphere of learning and the learning process so that learners can acquire knowledge, and actively develop the potential for him to have the spiritual power of religion, self-control, personality, intelligence, morality noble, as well as the necessary skills themselves, society, nation and state through the process of learning, guidance, direction, and ongoing training.

Definition of characters in the etymological principle, is a term derived from the Greek characters, namely kharaseein, which originally means engrave marks on paper or wax that serves as a differentiator (Karen Bohlin, 2005: 7). Thomas Lickona argued that the meaning of the character is, "A reliable inner disposition to respond to situations in a morally good way (Lickona, 2012: 51). From the above explanation, the notion of character is a way of thinking and behaving that characterizes the individual who delivered the good deeds without thought out beforehand and without consideration, to live and work; both within the family, community, nation and state to form a moral maturity in order to become a perfect man.

While the intent of the children here are born to parents, both same-sex male or female, large or small (Ibnu Mandzur, tt: 467). UNICEF (United Nations International Children's Emergency Fund) defines a child as the population aged between zero to eighteen years of age (Abu Huraerah, 2006: 19).

Thus, from multiple exposures above about character education of children, it can be concluded that the character education of children is a conscious and deliberate effort made by educators to students who are immature or have not experienced puberty and not yet 21 years of age in order to grow and bring forth deeds both to live and work, both within the family, community, nation and state to form a moral maturity in order to become a perfect man.

\section{METHODOLOGY}

This research was a qualitative one that intends to understand the phenomena experienced by research subjects' such as behavior, perception, motivation, and action 
holistically. Then, they will be described in a special context according to. (J.Moleong, 2009 :6)

The method of writing this research use library research (library research), the research done by collecting data and information by reading, studying and then analyze literatures relating to the theme, both primary (primary sources) and secondary (secondary sources). Then analyzed using content analysis method (content analysis) in the form of descriptive-Analytic

\section{FINDINGS}

In the view of Ibn Qayyim, faith is a basic staple in an educational process. Therefore, if a person has true faith in Allah, then he will be submissive and obedient to all things commanded and avoid any forbidden him. Thus, from the attitude would appear ihsan attitude / character well.

On the basis of exposure and explanation of the concepts of character education of children Ibnu Qayyim above perspective, an outline of the concept of character education of children according to Ibnu Qayyim emphasis on four important things, namely:

a. The importance of introducing kids to the God of monotheism

b. The necessity to teach children the principal teachings of religion

c. Teach and familiarize children good ethics and morals

d. exemplary

e. Praise and punishment educateIbn Qayyim Al-Jawziyya, his real name was

\section{DISCUSSION}

Muhammad bin Abi Bakr ibn Ayyub bin Sa'd ibn az-Zar'i Huraiz ad-Dimasyqi Syamsuddin Abu Abdillah, Ibn Qayyim al-Jawziyya (Ibn Rajab, 1953: 447). Known by the name of al-Jawziyya attributed to a madrassa established by Jamaludidin Shaykh Muhyiddin Ibnu Abi al-Faraj Abdurrahman bin al-Jawzi who died in the year $656 \mathrm{AH}$ (Hasan Al-Hijjaji, 1988: 38). For Ibnul Qayyim's father is a founder for the madrassa. Ibnul Qayyim was born in a knowledge and respectable family on 7 Saffar $691 \mathrm{H}$ or February 
4th, 1292 M. the village of Zara 'from Hauran township, southeast Dimashq as far as 55 miles (Ibn Rajab, 1953: 446). He was born and died in Dimashq (Az-Zurkaly, 1980: 56).

Ibn Qayyim al-Jawziyya studied Faraidh from his father because he was very prominent in the field. Learning Arabic of Ibn Abi al-Fath al-Baththiy by reading the book: al-Mulakhkhas li Abil al Balqa then book Jurjaniyah, Alfiya, also most of the book al Kafiyah was Syafiyah and most at-Tashil. In addition, he also learned from Syaikh Majduddin at-Tunisi one part of the book al-Muqarrib li Ibni Ushfur (Ibn Rajab, 1953: 446). earning science Shafiyuddin ushul of Shaykh al-Hindi, the science of jurisprudence of Shaykh al-Islam Ibnu Taimiyah and Syaikh Ismail bin Muhammad al-Harraniy. He is very proficient in science exceeded his friends, famous in all over the world and very deep knowledge of madzhab- schools Salaf (Ali As-Syaukani, 1348: 137). And in the end, he was really total in study (studied intensively) to Ibnu Taimiyah Ibnu Taimiyah after the return from Egypt in $712 \mathrm{AH}$ until his death in $728 \mathrm{H}$ (Ibnu Katsir, tt: 234).

Adh-Dhahabi rahimahullah said, "He had the attention to the hadith, whether related to honor or narrators, he also mastering Fiqh Sciences, Nahwu, Islamic Theology and Uhsul Fiqh." (Adh-Dhahabi, tt: 1500). Ibnul Qayyim rahimahullah had struggled to seek knowledge and studied intensively with theologians in order to obtain their knowledge and in order to master the various disciplines, especially the field of Islamic studies. His mastery unequaled to exegesis, his understanding Ushuluddin and knowledge about the hadith, hadith meaning, understanding and istinbath-istinbath complexity has reached its peak, difficult to find his equal.in order to master the various disciplines, especially the field of Islamic studies. His mastery unequaled to exegesis, his understanding Ushuluddin and knowledge about the hadith, hadith meaning, understanding and istinbath-istinbath complexity has reached its peak, difficult to find his equal.

Ibn Rajab said, "He, Rahimahullah died at the end of evening prayer time, the evening of Thursday 13 Rajab $752 \mathrm{H}$ or 23 September 1350 CE He was being prayed the next day, after noon, at the Jami al-Jarrah. He was buried at cemetery Babu Al-Sagheer. Many people who drove his body, there were many good people who dream about him, Rahimahullah (Ibn Rajab, 1953: 450). 


\section{ESSENCE OF MAN}

Humans are part of one of the elements of the elements present in an educational process. These elements include the spirit, mind, heart, and the human body. Between humans and education, can not be separated from each other. Both are an integral and interconnected, people as actors and as the education system in the process to achieve the goal of education itself.

Ibnu Qayyim al-Jawziyya noticed, that there are three elements that are present in humans: the element of materiality (psychomotor) that includes coaching body, skills (skills) and sexual education, elements of spiritual (affective) that includes the guidance of faith, character and will of god (the will), the element of intellect (cognitive) which covers development of intelligence and the provision of knowledge (Furqan Hasbi, 2006: 9). This view of human nature, is a central issue that will color shades of various facets of the civilization that built it. The importance of the concept of human beings in the system of thought and mind of a thinker, above all, is that human nature is a subject that knows (Collingwood, 1976: 1).

Therefore, the thought Ibnu Qayyim Al-Jauziyah of human nature, in line with the methodology of manhaj Islamiyyah. Where, he sees the whole person (syamilah wa mutakamilah), did not see the man from one aspect and viewpoint alone. As for man according to Ibn Qayyim al-Jawziyya are as follows:

1. Man was created on the authority and control of Allah. In essence, humans do need Allah in all things and circumstances. Humans desperately need him in terms of his divinity, his kindness and fulfillment of all requirements and their maintenance. Humans and creatures that exist in the natural world, experiencing many changes and shifts from one condition to another. It applies to all movements in the heavens and on the earth by the will, coercion, or natural, such as the movement of plants, natural movements, the movements of animals, heart and soul movement. All movement, change, and shift it will not happen unless their strength. And that power is only in the hands of Allah Subhanahu wa Ta'ala 
2. Man is derived from starch soil. In the book of 'Ar-Ruh', Ibnu Qayyim describe His creation of Adam, God said that he (Adam) was created from the ground. In another place, he created from black mud molded. In other parts as well, he was created from clay dry. Lafadz-lafdaz of it, even though there is a difference in meaning, but the substance is the same, namely from the ground. (Ibnu Qayyim, 1999: 279)

3. Man is the representative of Allah on earth. The position of the first man (Adam) as caliph has been established by God Almighty, who later on Al-Baqarah verse 31 shows, that the glory of Adam (men) on the Angels, where God specializes Adam 'upon whom be peace with the science / knowledge of the name- name everything (al-asthma ') that is not taught to the angels

4. Human beings are social creatures. humans are social beings who always need other people in his life. A human being can not live alone, and its existence is not done except by living together. He will not be able to perfect existence and life perfectly set individually.

5. Human beings think, was honored with wisdom, knowledge, character / characters are good, the ability to understand, and blessed with a nice shape. One of the advantages possessed by man is a science. With science, man is able to bring actions regulated and orderly (character) so that objects that exist as a natural resource can be processed and developed. In fact, control and use of living beings other than humans on earth, such as animals and plants. Because of the ability that man has made God as God's caliph al-ardhi Fi.

From some human characteristics above, it can be seen that the views of Ibnu Qayyim on the conception of man is the servant of God who live as social beings, creatures of learners who have the potential, strong will, and good taste / lust, which runs of eschatological in perfecting himself toward Allah Subhanahu wa ta'ala as Allah on earth.

The most fundamental problem, which is neglected by most experts education is the ideological foundation problems in education itself. A tree will not be able to stand firm without the support of the root (foundation) is strong. Therefore, the tree that stands 
firmly in need of a strong and firm roots anyway. Similarly, education, to shape the character takes a strong foundation solid as root or foundation.

Therefore, according to Ibnu Qayyim that the main cornerstone in building the character education of children is the foundation of monotheism (Ibnu Qayyim, 2009: 58). Tawhid is the beginning of the obligation to be met by a servant to his Lord. Therefore, it becomes mandatory for parents or teachers to provide teaching their children about faith as-shahihah and give them to them the dangers of shirk and warn them not to get caught into the case Shirk, either shirk in science or shirk in worship ,

Instead, knowledge of the origin of human events is very important in formulating educational purposes for human beings. The origin of this incident, it should be used as the base starting in setting outlook on life for the man himself. Ibnu Qayyim al-Jauziyah argues that the purpose of education in general is keeping human nature and prevent it from deviation and error. In addition, to instill good moral values and brushed off the bad morals, to explore the potential and find happiness in the world and in the hereafter by making all the activities as worship (Ibnu Qayyim, 2009: 5), which includes the destination Ta'abbuddiyyah (worship), akhlaqiyyah (coaching character), 'aqliyyah (development intelligence), maslakiyyah (development of talents and interests), and jasmaniyyah (development of physical health), (Hasan Al-Hijjaji, 1988: 320).

In the educational process, the curriculum is an urgent part of the educational process, as the purpose of life is believed to be the truth can be achieved through curriculum planning (Ahmad Tafsir, 2013: 82). The curriculum is an educational process systematically arranged under the responsibility of the school in a learning program provided to students to develop the knowledge, skills and attitudes of students. The children's character education curriculum from the perspective of Ibnu Qayyim is an integrated curriculum / methodology of at-takamul (integrated curriculum), which includes several curriculum (Ibnu Qayyim, 2005: 110- 248). Including the following :

1. Curriculum Tauhid. Tawhid is the basis of the most fundamental teachings of Islam. Introducing faith and Tauhidullah to children is the most urgent and essensial lesson, because the lives of Muslims rotating, and formed with it. Faith in God is the principle peak in the general system of life of Muslims as a whole. 
The first thing that should be emphasized and given to a child is education about the faith, namely to install tawhid to children as early as possible and Teach children the principal teachings of Islam. Children in the early period of growth and development should be given education on the subjects of religion, through referrals, guidance and coaching as much as possible so that they can grow and develop as pious children who has a good personality.

2. Curriculum Behavior. character is Minhajul life (way of life) for a Muslim. Because, good Muslims behaviour always showed in his life and cover their days. Behavior associated with the temperament of a person which includes in it the nature of patient, courageous, itsar (concerned with others than himself), gratitude, generous, honest, and trustworthy. All of which is the implementation of the general character (Hasan Al-Hijjaji, 1988: 313). Islam recommends to educators in order to seed and nurture their children with ethics and morals of Islam. Because of such, including rules that made Islam to educate children so that interaction between children and families and other people are always built upon a noble character and amiable neighbor

3. Curriculum fikriyah (intelligence). Sense is a tool (the means) to acquire knowledge, which is used as scales to determine truth from error, knowing that higher priority virtue of which do not, and as a reflection to know the good from the bad.

4. Curriculum Ruhiyyah. Soul and body influences one another, as befits two allies in deed, and the soul can be alone in causing the influence of which can not be shirked by the body. While the body does not have the power of influencing without shriked by the soul. ((Ibnu Qayyim, 1999: 331). Man consists of two elements, namely the element consisting of body and spirit, so that human beings and ruhiyah jasadiah once. Their relationship is like the relationship between a captain with a boat, which serves as a regulator and the helmsman steering the boat course objectives, and the soothing flow of water carrying and keeping the boat in the middle of the blast wave. (Saad Riyadh, 2007: 46). Ruhiyah provide education to children is something that is very urgent, because the soul is like a 
mirror. Considering whether or not the behavior and character of the person depends on the quality of the soul itself. If the soul good, it will give birth to a good character as well. Vice versa, if the soul sick, then it will bear the bad behavior and negative. One of the key points in the character education of children is allowing children to pray Tahajjud. Night prayer (Tahajjud) is one that has a distinctive worship and virtue as a means to draw closer to Allaah. Worship that can purify the soul and cleanse the perpetrators of sins and errors, and can prevent the perpetrators of acts of sin and sinners

Thus, it is clear that the soul can be nurtured and trained to become a good habit, so it can be expressed with the appearance of good character and behavior as well. For character education should be started from the upstream, not downstream, which starts on the inside (soul) of the children themselves.

6. Psychological Curriculum. In a process of character education of children, curriculum related to the child psychologically is very important and noteworthy. Because psychology is an important part and one of the elements of education ruhiyah itself, in order to charge children's character education materials to meet needs that dimension ruhiyah (spiritual). Humans have gharizah (instinct) or instinct to develop according to its growth, as well as to give effect to the words and behavior, either useful or useless deeds.

7. Social Community curriculum. Appropriate human nature and the nature of the case,

8. requiring interaction with the public, which means that people require cooperation among themselves in order to live; either for food and defend themselves. Social relationships is something that is vital in human life. If social relationships do not exist, then they are not perfect beings and not realized what was intended by Allah in the form of prosperity in the world and make them as His vicegerent on earth (Ibn Khaldun, 2011: 1).

9. Curriculum Interest and Talent. In the world of children's education, knowing the potential of students and understand their interests and talents are very urgent for parents and educators. This relates to the development of their souls; ruhiyah both 
dimension (spiritual) or dimensionless jasadiyah (physically). Therefore, if the interest and talent is not directed toward the right, then he'll take to the way of improper interest and plunges himself into negative actions. Thus, the character education of children, needs a program as a vessel in a process of development interests and talents of the child, so the child's potential can be developed and directed towards a positive way and beneficial for their future.

10. Curriculum Dexterity. Exercise is one of the means to control the development of the physical health of children. Therefore, regular exercise can maintain health and fitness. Because the move is one of the therapeutic treatment of certain diseases. Each limb has its corresponding specific sport. Exercise of the brain is reading, starting with reading aloud slowly up gradually. Exercise ear is to listen and to talk gradually, ranging from mild to severe talks. Similarly, the exercise of the tongue, is done by talking. Sporting eyes done with a look. Sport foot by walking gradually, little by little (Ibnu Qayyim, 2004: 192).

11. Curriculum Jinsiyyah. What is meant by curriculum jinsiyyah here is a process in providing a good understanding to the children about adaptation and adjustment in life; both now and in the future in accordance with jinsiyyahnya (gender), (Mahdi Al-Istanbuly, $1402 \mathrm{H}$ : 17). It has become human nature that they have a tendency that is like the opposite sex. Adolescent phase is a period that is very dangerous and prone to human life. Therefore, the responsibility for parents and educators to keep children out of every thing that can stimulate their lust and moral ruin is an obligation that must be done. Providing an understanding to the children about Jinsiyyah (gender) is a very important thing to get attention.

Integrated curriculum above, can run smoothly in the process of character education of children if it is supported by the methods and means which are appropriate, effective, and efficient. In the view of Ibnu Qayyim, the proper method is applied in character education of children are : Coaching Method, Method Care, Treatment Methods and reward and punishment Method. 
Fostering of the mental and spiritual is needed, by introducing students to God the Creator, to advise and remind the child if you make a mistake, get children to apologize and to forgive, to teach children ethics and courteous, and get children to live disciplined and consistent approach to religion. All that is done in the form of mental and spiritual development of children through worship as a means of holistic-based.

Guarding against moral attitudes of children should also be carried out, in order to keep the child from the negative influence of the people around him. By giving the example to children, parents deliver their speech, behavior and attitude in the face of a child, to give an example to children in worship, ethics, and manners in the act. Teach children saying good, kind and useful words. It has become an obligation for parents or educators to educate and direct the children in saying good and positive words and keep children out of saying dirty and nasty as well as from other negative words. Because, saying vulgar and obscene is a reflection of the soul dirty. There is a match between the dirty soul with filthy behavior anyway.

One of the key points in the character education of children is get the kids to ask for permission. Either permission when taking something that was not hers, nor ask for permission when he would go into his parents room. If a child is accustomed to taking the property of others, then it will become a habit. So he grew up with behavior like taking without permission (ghasab / steal), and do not like to give and share with others.

Teach children said words were kind and helpful. It has become an obligation for parents or educators to educate and direct the children in saying that good and positive and keep children out of said dirty and nasty as well as from other negative words. Because, say vulgar and obscene is a reflection of the soul dirty. Because of this there is a match between the soul dirty with filthy behavior anyway.

Keep children out of saying false and treacherous. Honesty is a behavior based on efforts to make the person as a reliable,good saying person both in actions and work. Honest means no lying, no cheating, genuine and sincere (Abdillah Syukur, 2014: 137). Instead, lie or falsehood can drag the culprit to sin, soul and feeling anxious, far from favor and facilitate the culprit doing negative things that harm themselves and others 
Keep children from places of vice and the environment is not conducive. Character education can be taken as a lesson for a child is a child away from the environment that is not conducive, and keep children from things that can melalaikannya of obedience to God. Son is a mandate for the master. His heart is a pearl of pristine and pure, ready to set up a wide variety of any kind. If the manner of goodness, of course he will grow in goodness. Vice versa, if socialized into disrepute, then he will grow in such vices. A child who does not get the teaching of manners, manners or grammar spell as a child, then he is easily influenced by the surrounding environment, so that he would swallow the bad influence from the environment without being able to filter and sort promiscuous and distinguish between what is good and what is bad.

Keep the boys from the look feminine, and educate a boy into a real man. instill character heroism for boys since childhood is one of the means to prevent the tendency towards same sex and of irregularities sexsual. To that end, training, fostering and directing them according to the nature and sex is a matter that should receive the attention of parents and educators. For, if the children are left without any guidance, it will be more and more psychiatric illnesses that befall them as gay, lesbian, transgender and other deviant behaviors.

Besides these two methods, the method of treatment also needs to be done by educators to their students, in an effort to maintain his sanity and add positive energy to the child with psychological therapy, knowing psychiatric and potential of children and meet their needs at every phase, appreciate and listen child speech and opinion, and last but not least, social minded train to children. with Sadaqah, fasting, generous and altruistic.

Allowing a child to give and to empathize with others. Giving and empathy is a form of social and environmental concerns surrounding environment, the sensitivity to be able to help people around that need. So that the local community can get benefit. Instead of that, giving and empathy for others will foster a sense of compassion in children to among fellow. If this continues to be developed, it will be a positive behavior for the child, and come up to children with good character in the association or sociable with others. Instill good character since early childhood. Islam recommends to educators in order to 
seed and nurture their children with ethics and morals of Islam. Because of such, including rules that made Islam to educate children so that interaction between children and families and other people are always built upon a noble character and amiable neighbor

The mental health of a child is very important to get attention. Soul of the child if it has reached the degree of muthmainnah nafs (soul that is stable), which has three main characteristics that reinforce each other, namely; (1) people who believe in Allah, (2) people who are patient, (3) people who surrender themselves to God (trust). Then it will be easy to give birth to noble deeds, so that can be formed into a character and a good personality.

One of the method in the character education of children is provide educational reward and punishment. Punishment is not an educator retaliation to their students. However, the real purpose is educational and is one method of teaching. Reward and punishment to children is part of the educational process. give praise and gifts to children is a form of appreciation to them. And inflict punishment on them are teaching. Therefore, children punished for education, not torture.

Including the most important means of shaping the character of children is by making use of their spare time to do positive activities, productive, and sportsmanship, as well as beneficial. It is as a means to develop the potential of children in work and work. So it will be easier for them in their adulthood to be more productive and innovate in their work, as well as honest and responsible in implementing the human relationship with their business partners.

Directing children according to their interests and talents. Among the important matters that must be recognized by educators well is knowing the tendency of children to the skills, interests and talents and the work suited him, as well as the ideals that he wants to get (Nashih 'Ulwan, 2012: 445). Each child has a different character, intelligence, and the potential between one child and another. To that end, educators and parents need to pay attention and directing children according to their interests, talents, abilities and potential. One method that is appropriate to develop the potential of children by granting wishes and directing talent of children. children ask what he needed. If granted, the heart will feel 
very happy. If the request is not granted, he will be upset and angry and will perform unwanted actions (Abdul Hafidz Suwaid, 2012: 203).

\section{CONCLUSION}

Waning values of character education on students, in fact motivated because faith does not serve as the basis of philosophical education. theories of education on children's character mostly adopted from Western theories are more likely to understand secularism. It is time for education practitioners, educators and parents of students to change the mindset towards faith-based education. For Ibnu Qayyim, act or activity should always expect a reward from Allah Subhanahu wa Ta'ala. Every plan, business, and any activities that will be carried out should always rests in Allah Subhanahu wa Ta'ala, including in educating and shaping the character of children, because educating children is a faithbased and religious obligation that was ordered.

Character education is an important part of human life, because it will shape the personality of the man himself. The presence of the Apostles and Prophets sent by God Almighty on this earth is to improve the character / morality. Therefore, the civility of a nation depends on the level of national character itself. So, we have to do is to Faith and fear Allah Subhanahu wa Ta'ala. The core in character education curriculum, as one source of character education of children that is good and right are based on religious teachings. The outline concept character education of children perspective Ibnu Qayyim emphasizes on four important things, namely: the importance of introducing kids about the monotheistic God, the need to teach children the principal teachings of religion, teach and familiarize children ethics and good morals, the importance of exemplary, and praise and punishment educate.

\section{BIBILIOGRAPHY}

Al-Jauziyyah, Ibnu Qayyim, 2009. Kunci Surga Mencari Kebahagiaan Dengan Ilmu, Terj. Abdul Matin dan Salim Rusydi Cahyono, Solo : Tiga Serangkai

Al-Birkawi, Muhammad Pir Ali, 2015. The Book of Character, Jakarta : Zaman

Collingwood, R.G. 1976. The Idea of History, New York : Oxford University Press, , 
hlm. 205

Husaini, Adian, 2005. Wajah Peradaban Barat dari Hegemoni Kristen ke Dominasi Sekuler-Liberal, Jakarta : Gema Insani

Mandzur, Ibnu, tt. Lisan al-Arab, Beirut : Daar as-Shadr

Rajab, Ibnu, 1953 M / 1372 H. Kitab adz-Dzail 'Ala Thobaqat Al-Hanabilah, Penerbit Al-Sunnah Al-Muhammadiiyah

Syukur, Taufik Abdillah, 2014. Pendidikan Karakter Berbasis Hadits, Jakarta : RajaGrafindo Persada

Tafsir, Ahmad, 2013. Ilmu Pendidikan Islami, Bandung : PT. Remaja Rosdakarya

‘Ulwan, Abdullah Nashih, , 2012. Tarbiyatul Awlad Fii Al-Islam, Terj. Solo : Insan Kamil

Wiyono, Edy, 2008. 37 Kebiasaan Orang Tua yang Menghasilkan Perilaku Buruk pada Anak, Jakarta : PT Grasindo, 